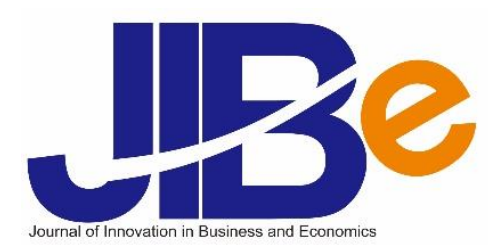

\title{
Strengthening work engagement through digital engagement, gamification and psychosocial safety climate in digital transformation
}

Arief Dwi Saputra ${ }^{1}$, Alfina Rahmatia ${ }^{2}$, Sri Handari Wahyuningsih ${ }^{3}$, Arni Surwanti ${ }^{4}$

\author{
Management Department, Universitas Muhammadiyah \\ Yogyakarta, Yogyakarta, Indonesia ${ }^{134}$ \\ Management Department, Universitas Ahmad Dahlan, \\ Yogyakarta, Indonesia ${ }^{2}$
}

DOI: $\underline{\text { https://doi.org/10.22219/jibe.v5i01.17477 }}$

\begin{abstract}
The problem faced in technological developments and during the pandemic is transforming employee habits from offline to online work engagement. This research aims to look at empirical evidence regarding the relationship between digital engagement, gamification, and psychosocial safety climate (PSC) on work engagement. This study employs a quantitative approach with structural equation modelling, analyzing a series of exploratory and confirmatory factors to determine the relationship between variables. This study uses primary data through a questionnaire of as many as 164 respondents with a purposive sampling technique. This study proves that digital engagement and gamification variables on PSC and work engagement have a significant positive effect. Aspects of digital transformation through digital engagement and gamification influence PSC to increase work engagement. The relationship between gamification channelled through PSC can also mediate and prove a positive influence in strengthening work engagement.
\end{abstract}

Keywords: Digital Engagement; gamification; psychosocial safety climate; work engagement

\section{Introduction}

Human resources management practices can go beyond work habits and can affect work engagement more effectively. However, in reality, only a few employees in the world have been involved in their work. Even the percentage of employees who are not involved is more than the employees who have been involved with their work, not only in the world but also in Southeast Asia and Indonesia. This is indicated by the results of Gallup (2017) research in its report entitled State of the Global Workplace, only $15 \%$ of employees worldwide are involved or very involved and they are enthusiastic about their work and their workplace, while the other $67 \%$ are not involved or psychologically unconnected to their job and business.

Since their engagement needs are not fully met, they devote time but not energy or passion to their work, and the remaining 18 percent of employees are actively disengaged or are unhappy at work but are angry that their needs are not being met are expressing their dissatisfaction. Every day, these employees have the potential to undermine the efforts of their coworkers. In Southeast Asia, 19\% of employees are actively engaged, $70 \%$ are not engaged, and the remaining $11 \%$ are actively disengaged. In Indonesia alone, $15.4 \%$ of employees are involved, $76.5 \%$ are not engaged, and the remaining $10.3 \%$ are actively disengaged (Gallup, 2017).

According to a Dale Carnegie study, only $25 \%$ of millennial employees in Indonesia are fully engaged (fully engaged) in their workplace, $66 \%$ are only partially engaged, and the remaining $9 \%$ refuse to be involved (disengaged). In comparison, For Generation X, 29\% of employees are fully involved in the company they work for, $62 \%$ are only partially involved, and the remaining $9 \%$ refuse to be involved (Dale Carnegie, 2017). Gallup's research results also show differences between business units in the upper and lower quartile. Research in engagement shows that the upper quartile business units have better engagement scores than the lower quartile business units, ranging from absenteeism, productivity, turnover, level of engagement. Incidents, sales, and profitability. This creates a psychosocial safety climate (PSC) on employees' perceptions of the policies formed by the organization psychologically.

${ }^{1}$ E-mail: ariefdwisaputra18@gmail.com 
In addition, the upper quarter business units are more aware of what employees want and need to maximize work engagement potential. The development and penetration of technology in the world cause a new dilemma where technology becomes a necessity in human life. The results of Kemp's research in Digital 2019 by Hootsuite \& We Are Social (2019), as of January 2019, the penetration of digital engagement in the use of gadgets and the global internet was 5.11 billion and 4.39 billion, respectively, where the total world population at that time reached 7.68 billion people. In Indonesia alone, as of January 2019, there were 355.5 million digital engagement users in telecommunication services and 150 million internet users out of Indonesia's total population of 268 million. With the high penetration of digital engagement, it can help companies achieve work engagement for their employees.

Technological developments in other gaming fields in the form of actual reality have also given rise to a phenomenon. This is an opportunity for HR management to put game design theory into practice in their daily work. The application of game design theory to work is called gamification (Deterding et al., 2011). The use of gamification itself can help a company to achieve employee work engagement. In gamification, employees will feel happy because they will work like playing. Besides that, through gamification, employees will feel more motivated and challenged. In addition, the shift in the economic system from offline to online during the pandemic resulted in reduced work engagement with the implementation of WFH.

For this reason, this study will examine the influence between digital engagement and gamification associated with psychosocial safety climate on employee work engagement. This research aims to look into work engagement issues and see how they affect the review of digital engagement gamification and psychosocial safety climate (PSC) variables. This research will contribute to the academic literature and can be developed for future research on work engagement by discussing issues such as online-based MSME business productivity in the face of a pandemic. Then, work engagement can be implemented from a practical point of view of digital engagement, and gamification provides psychological health in the perception of digital transformation.

\section{Literature Review \\ Work Engagement}

According to Pham and Avnet's article, work engagement theory is seen as being based on the primary regulatory involvement, such as the values of work engagement can be defined as the motivating force that a person feels as attraction or rejection of an object that comes from the process of achieving specific goals (Pham \& Avnet, 2019). In contrast to Pham and Avnet, who explain the involvement of engagement values, according to Beck, there are three types of work engagement. The first is personal engagement which is determined by one's ambition even if someone skilled but unmotivated will do the job only to the extent of doing it and will not go beyond what is required conversely if someone motivated will achieve more work more creatively and happily than someone who does not are motivated.

The second is organizational engagement which is determined by organizational culture and the quality of its leaders as measured by how someone spends their time and efforts for the organization. Someone will be more enthusiastic when starting a career in the company but will be weaker if they respond to poor leadership or dysfunctional corporate culture. Third, there is situational engagement which is determined by the significance of the initiatives carried out in the company, how involved and enthusiastic people are in the initiatives that someone asks of the company (Michael Beck, 2015)

Meanwhile, according to Saputra, three types of engagement are interdependent; namely, there is an engagement driver who has four variables, namely personal resources, work-related, social, and organizational support affecting work engagement which affects engagement outcome. Work engagement can be classified into four categories: physical, emotional, intellectual, and spiritual. The last is engagement outcome which has a variable impact on attitudes, behaviour, and business (Saputra, 2016). Based on the literature above, it can be explained that engagement is a determined person's involvement in responding to something to achieve his goals. The achievement of this goal can be determined by the determination and motivation of the person himself, and each person has a different determination and motivation to achieve a customized goal in different situations.

\section{Digital Engagement}

Digital engagement is a person's digital engagement to reflect digital inclusion, focusing on the shift between technology users and non-technology users. The use of digital engagement itself refers to the way a person uses and participates in content activities and internet platforms, which means that the use of technology is now integrated into everyday life, which identifies the involvement of technology in the skills of a person (Helsper \& Eynon, 2013). Digital engagement can also be defined as how much or frequency a 
person engages in online activities.

There are three levels of construction in digital engagement: essential digital engagement, intermediate digital engagement, and advanced digital engagement. The basic level of digital engagement is the most often encountered, where someone uses technology to communicate with friends or relatives, play video games and upload photos or videos. For the intermediate level of digital engagement, someone uses technology to make online purchases, e-banking transactions, and browse official websites such as official government websites, work, and so on with related work. Meanwhile, at the advanced level of digital engagement, someone uses technology to read online news, create groups to discuss related issues and carry out social activities (Samsudin \& Hasan, 2017).

It is not only the difference between technology users and non-technology users and with the various activities of using technology itself. Digital engagement has an essential role in encouraging employee engagement at work. Digital engagement changes the way workers relate to their colleagues in the company. These changes are changing the way employees communicate and collaborate to encourage behaviours critical to the company's success (Jesuthasan, 2017).

\section{Gamification}

Gamification is applying design theory in the form of games by incorporating game design elements into non-game contexts, such as business. Gamification has a simple concept, namely by redesigning routines in the office such as training and recruitment that are made like games like video games or interactive games that have the primary goal of enhancing a more exciting work experience (Simpson \& Jenkins, 2015). However, gamification still needs to be developed and build a solid theory to reach its maximum potential and needs to be aligned with company goals to be appropriately implemented to prevent failure (Gupta \& Gomathi, 2017).

The application of game elements that can be applied within the company can be in the form of points, levels, and others, with the primary function of attracting and increasing employee motivation (Saputra \& Rahmatia, 2021). Gamification is also a blend of old and new applications in business management, with one example being the old implementation of the company providing the value of employee information to direct and improve employee performance. In contrast, the new company's gamification can provide employee performance information with real-time access. And continuous information on employee performance in the company (Cardador et al., 2017).

\section{Psychosocial Safety Climate (PSC)}

According to Dollard \& Bakker (2010), the definition of a psychosocial safety climate (PSC) is an employee's perception of the organization's policies, practices, and procedures for ensuring employees' psychological health and safety. Furthermore, he believes that PSC is a specific organizational component that is intended to improve employees' psychological health and safety, which is expected to affect working conditions. Tuckey et al. (2013) explained that PSC is a normative concept or assessment of "good work/healthy work" where a manager thinks about the welfare of his employees.

Company management will design job demands to be more organized. In organizations with a high PSC level, the demands of the work given will be involved so that problems regarding the psychological health of employees are not a significant problem. However, in organizations with low PSC levels, managers are not worried about how much workload is given or other problems such as bullying, affecting employee stress levels. PSC is a form that reflects the organisation's success in managing employee welfare (Bakker et al., 2010).

\section{Hypothesis \\ Relational Digital Engagement and Work Engagement}

Digital engagement has a positive impact on work engagement. This statement is supported by research conducted by Goswami \& Upadhyay (2019), which shows that the digital transformation aspect is a good predictor of employee engagement. There is a relationship between digital transformation and employee engagement and how far the components influence employee engagement. Jesuthasan (2017) also stated that the results of research exploration of digital technology have changed the way workers relate to coworkers and organizations, and digital technology has changed how work is done. In addition, the results of research from Bhuvanaiah \& Raya (2016) explain that, Employees are moderately attached to their jobs on average. Organizational culture is a significant predictor of transformational leadership and job attachment. Leadership has a significant positive effect on performance, while employees attached to their work will have high performance in an organization (Fujimoto et al., (2016). 


\begin{tabular}{|c|c|}
\hline Authors' & Findings \\
\hline $\begin{array}{l}\text { Goswami \& } \\
\text { Upadhyay (2019) }\end{array}$ & $\begin{array}{l}\text { The results show that the digital transformation aspect is a good predictor of employee } \\
\text { engagement, and there is a link between digital transformation and employee engagement, and } \\
\text { the components have a significant impact on strengthening employee engagement. }\end{array}$ \\
\hline $\begin{array}{l}\text { Vayre \& Vonthron } \\
\text { (2019) }\end{array}$ & $\begin{array}{l}\text { According to research, there is a link between the company's technology tools and personal } \\
\text { internet use. Furthermore, intensive, widespread, and pivotal use of the internet for work } \\
\text { promotes permeability between work and personal life, reduces enthusiasm and dedication at } \\
\text { work, and encourages addiction. }\end{array}$ \\
\hline Jesuthasan (2017) & $\begin{array}{l}\text { The results of exploratory research show that digital technology has changed the way workers } \\
\text { relate to coworkers and organizations, and digital technology has changed how work is done. }\end{array}$ \\
\hline $\begin{array}{l}\text { Bhuvanaiah \& } \\
\text { Raya (2016) }\end{array}$ & $\begin{array}{l}\text { According to the findings, the average employee was moderately attached to his or her job. } \\
\text { Organizational culture is a significant determinant of transformational leadership and work } \\
\text { attachment. Employees attached to their work will perform well in an organization because } \\
\text { leadership has a significant positive effect on performance. }\end{array}$ \\
\hline $\begin{array}{l}\text { Lockton et al. } \\
(2012)\end{array}$ & $\begin{array}{l}\text { The study's findings indicate that digital engagement has a significant impact on employee } \\
\text { engagement and workplace sustainability. }\end{array}$ \\
\hline $\begin{array}{l}\text { Prasad et al. } \\
(2019)\end{array}$ & $\begin{array}{l}\text { The study's findings indicate that the five dimensions of the corporate gamification } \\
\text { effectiveness scale highlight how employees perceive corporate gamification and that there is } \\
\text { a positive and significant relationship between employees' perceptions of gamification and } \\
\text { employee engagement. }\end{array}$ \\
\hline $\begin{array}{l}\text { Ērgle \& Ludviga } \\
(2018)\end{array}$ & $\begin{array}{l}\text { According to research, gamification has a positive and significant effect on job satisfaction } \\
\text { but does not affect engagement. }\end{array}$ \\
\hline Alsawaier (2018) & $\begin{array}{l}\text { There has been little research into the effects of gamification on motivation and gamification } \\
\text { on multiple levels. There is a gap between theory and practice in the study of gamification. In } \\
\text { addition, there is a paucity of literature on gamification design implementation guidelines. }\end{array}$ \\
\hline $\begin{array}{l}\text { Dollard \& Bakker } \\
(2010)\end{array}$ & $\begin{array}{l}\text { Psychosocial safety climate (PSC), such as management support and commitment, is an } \\
\text { attitude applied by the organization that can affect employee engagement (engagement). }\end{array}$ \\
\hline $\begin{array}{l}\text { Bakker \& } \\
\text { Schaufeli (2014) }\end{array}$ & $\begin{array}{l}\text { PSC management priority refers to employees' perceptions of the organization's commitment } \\
\text { to maintaining employees' psychological well-being to provide feedback or responses that } \\
\text { demonstrate their dedication to their work, such as by putting forth their best effort when } \\
\text { working. }\end{array}$ \\
\hline $\begin{array}{l}\text { Gupta \& Gomathi } \\
\text { (2017) }\end{array}$ & $\begin{array}{l}\text { Gamification has been applied in various industries to involve employees and customers, } \\
\text { learning and development, performance improvement, recruitment, and others. However, } \\
\text { gamification still needs to be developed and build a solid theory to reach its maximum } \\
\text { potential and needs to be aligned with the company's goals to be appropriately implemented } \\
\text { to prevent failure. }\end{array}$ \\
\hline $\begin{array}{l}\text { Lawande et al. } \\
\text { (2016) }\end{array}$ & $\begin{array}{l}\text { The findings demonstrated that gamification could be used as a powerful tool to improve } \\
\text { company performance outcomes. In a business context, HR's role in policy development and } \\
\text { implementation of employee engagement is critical. Gamification can increase employee } \\
\text { engagement and position oneself in a more strategic role within the organization. }\end{array}$ \\
\hline $\begin{array}{l}\text { Robson et al. } \\
\text { (2015) }\end{array}$ & $\begin{array}{l}\text { According to research, gamification is a tool businesses can use to improve and develop their } \\
\text { interactions with various stakeholders. Gamification will generally be successful if the } \\
\text { company can align the gamification design with the player's specifications (target). }\end{array}$ \\
\hline $\begin{array}{l}\text { Saha \& Pandita } \\
\text { (2017) }\end{array}$ & $\begin{array}{l}\text { This research shows that Gamification is not always about making games. Gamification made } \\
\text { HR more fun and engaged without destroying their credibility and motivated employees to } \\
\text { keep learning. Engagement is an essential measure of Gamification's success in the midst of } \\
\text { increasing technological capabilities. }\end{array}$ \\
\hline
\end{tabular}

Based on several theories that have been mentioned, digital engagement is mastery of digital technology that can improve the ability to solve problems of daily life, both in terms of socializing, doing business, and playing a role in the broader community. Dimensions and indicators of digital engagement differ in a person's online activities (Samsudin \& Hasan, 2017). There are 3 aspects of digital engagement that match our research, namely: Basic digital engagement, communicating with friends or relatives, playing video games, listening to music, watching videos, and uploading photos or videos; communicate with friends or relatives, play video games, listen to music, watch videos, and upload photos or videos; Intermediate digital engagement, online shopping, e-banking transactions and finding information for learning purposes and Advance digital engagement, reading online news, creating groups to discuss related issues, and conducting social activities.

H1: Digital Engagement has a positive effect on work engagement 
Relational Gamification and Work Engagement

Gamification has a positive impact on work engagement. This statement is supported by research conducted by Prasad et al. (2019), which produces five dimensions of the corporate gamification effectiveness scale highlighting how employees perceive corporate gamification. It also demonstrates a significant and positive relationship between employees' perceptions of gamification and employee engagement. There is a scarcity of research on the effects of gamification on motivation and gamification on multiple levels. The theory and practice of business studies in implementing gamification designs are also limited but can be developed in work engagement (Alsawaier, 2018). Gamification has been applied in various industries to involve employees and customers, learning and development, performance improvement, recruitment, and others.

Based on several theories that have been mentioned, gamification is an approach in the form of realtime feedback from the application of game or game principles in managing jobs in an organization so that it has a positive impact on work engagement and productivity. Dimensions and Indicators of Gamification Measures that match this research have 3 aspects, namely: Purpose, application of game elements, alignment of employee goals with the company; personal motivation, motivation, rewards in the form of points, badges, levels and other incentives and performance, skills development, company feedback to employees, access to employee performance results, and employee challenge levels (Saputra \& Rahmatia, 2021).

H2: Gamification has a positive effect on work engagement

\section{Relational Digital Engagement and Psychosocial safety climate (PSC)}

Employees are human resources who are the most critical factor as a driver and driver of the success of an organization or company. As the most crucial factor in an organization or company, of course, the organization or company requires qualified and competent employees to face the competition that occurs. Arief (2020) states that workload affects performance, where a high workload will cause errors that can arise due to the inability of employees to cope with demands at work. So, in this situation, digital engagement becomes essential and must be owned by employees.

Tuckey et al. (2013) assume that PSC is the leading indicator that affects psychological working conditions, psychological health, and employee engagement. Furthermore, Dollard \& Bakker (2010) also found some evidence that PSC is directly related to job resources through digital management, affecting employee work engagement, where PSC is a vital organizational resource that can affect digital engagement. In line with this, Dollard \& Bakker (2010) reveal that the demands of the times through this digitalization era impact one is psychological health and engagement.

\section{H3: Digital Engagement has a positive effect on psychosocial safety climate (PSC)}

\section{Relational Gamification and Psychosocial Safety Climate (PSC)}

Job demands affect the health of employees by the source of the work they use. PSC is an employee's thoughts or perceptions regarding the organisation's policies, practices, and rules to maintain psychological health and safety. This is what makes the company look for a managerial system solution. Saputra \& Rahmatia (2021) explained that gamification has a relationship with psychological effects. This refers to the theory of gamification, which is defined as playing while doing business (Robson et al., 2016). Bakker et al. (2010) revealed that gamification in PSC can be a policy formed by the organization through practices and procedures to maintain employees' psychological health and safety. This is because this theory is continuous with aspects of the psychosocial safety climate, used as a reference in making gamification strategies.

Gamification also plays a role in motivating employees when employees face high job demands that can cause stress. Thus, employees can be more enthusiastic (vigour) in doing their work and have higher mental resilience. While PSC refers to employees' perceptions of the extent to which the organization values contributions, provide support, and cares about their welfare. The higher the concern and participation of the organization are paying attention to the welfare of its employees, the higher the organization's efforts in creating a work environment that can support the performance of their employees so that these employees will later understand their role in the organization (absorption). This aspect is related to gamification, a form of social support that comes from the work environment, both superiors, management, and colleagues (Mitchell et al., 2020).

H4: Gamification has a positive effect on psychosocial safety climate (PSC) 


\section{Relational Psychosocial Safety Climate (PSC) and Work Engagement}

Psychosocial safety climate (PSC) aspects such as management support and commitment indirectly play a role in influencing employee attitudes (dedication) in doing a job. Management support and commitment is an attitude applied by the organization that can affect feelings of engagement (engage) in employees. If the organization shows an attitude or behaviour that reflects its loyalty to their employees, then these employees will feel valuable so that they provide feedback or replies, which are shown by their dedication to their work, for example, by giving their best effort when working (Silic et al., 2020).

The company's efforts to create employees who are engaged in their work are not accessible. Increasing work engagement can be done by creating a work environment that can support employee performance and productivity physically and psychologically. One of them is through psychosocial safety climate (PSC). PSC, in this case, acts as an external factor that can support the creation of work engagement within employees. PSC is a set of perceptions regarding policies, practices, and procedures to maintain employees' health and psychological safety created by employees (Pesare et al., 2016). Thus, PSC is indirectly related to work engagement.

H5: Psychosocial safety climate (PSC) has a positive effect on work engagement

\section{Psychosocial Safety Climate (PSC) Can Mediate the Influence Between Gamification and Work Engagement}

According to Dollard et al. (2012), PSC aspects of work engagement are Management support, which is a form of commitment, and company support in maintaining the welfare and psychological safety of employees so that employees feel comfortable when working. Furthermore, Management priority is a measure of how important an organization or company views PSC in the company to maintain their employees' safety and psychological health. Organizational communication is a communication technique carried out by management to subordinates in providing direction, motivation, and other things to employees. Organizational participation and involvement are the intensity of management participation in an organization or company in creating and maintaining a conducive work environment (Hanaysha, 2016).

The development of existing technology certainly changes people's lives in doing their jobs, especially with technology creating market conditions that continue to change or become more competitive. This situation makes companies increasingly dependent on their workforce to achieve success. Companies will need employees who feel energetic, enthusiastic, and absorbed in work within the company while maintaining psychology. PSC conditions will direct technological developments in increasing digitalization engagement. Digital engagement is essential because the company will be able to find out how significant the role of employees can be to encourage the level of work engagement (Garrick et al., 2014).

According to Lawande et al. (2016), in his research, gamification can be used as an influential tool to improve company performance results. The role of HR in policymaking and implementing employee engagement is significant in a business context. Gamification can encourage employee engagement and create a more strategic role for oneself in the organization. Kevin Werbach (2012) research shows that gamification is a way that companies can use to improve and develop the way they engage various stakeholders. Gamification will generally be successful if the company can align the gamification design with the player's specifications (target), which states that gamification positively affects work engagement.

H6: Psychosocial safety climate (PSC) can mediate the influence between gamification and work engagement

\section{Research Method \\ Samples \& Data Collection}

The data for this study were collected from employees at D.I. Yogyakarta. The choice of place was due to focus on the review and one of the areas affected by the pandemic period with a high increase in the positive number of COVID-19 (Badan Pusat Statistik, 2020). Respondents in this study are employees who are engaged in the MSME business. Determination of respondents based on purposive sampling technique with specific criteria (Creswell, 2019). This study adopts the definition of work engagement with technology based on research from Arief et al. (2021) with MSME criteria, namely (but not limited to): focus on reviewing employees who have worked for at least two years; permanent employees; digital work; and; understanding of using digital tools.

This study uses a quantitative strategy using structural equation modelling in the AMOS 24 application through a series of exploratory and confirmatory factors analyzed to determine the relationship 
between variables. Data collection through questionnaires and interviews. Respondents filled out questionnaires and were interviewed from 170 questionnaires, and 4 respondents did not fill out the questionnaire completely. The sample consists of 164 respondents who are representative of the research sample.

\section{Control Variable}

The relationship between digital engagement, gamification, and PSC on work engagement should be examined while controlling for firm characteristics such as size. Some empirical evidence supports the claim that MSME business size is among the most important predictors of engagement. Based on the literature review, the framework in this study explains the importance of digital engagement, gamification, and PSC on work engagement to increase engagement. Relational digital engagement and gamification will increase PSC, which in turn leads to increased work engagement.

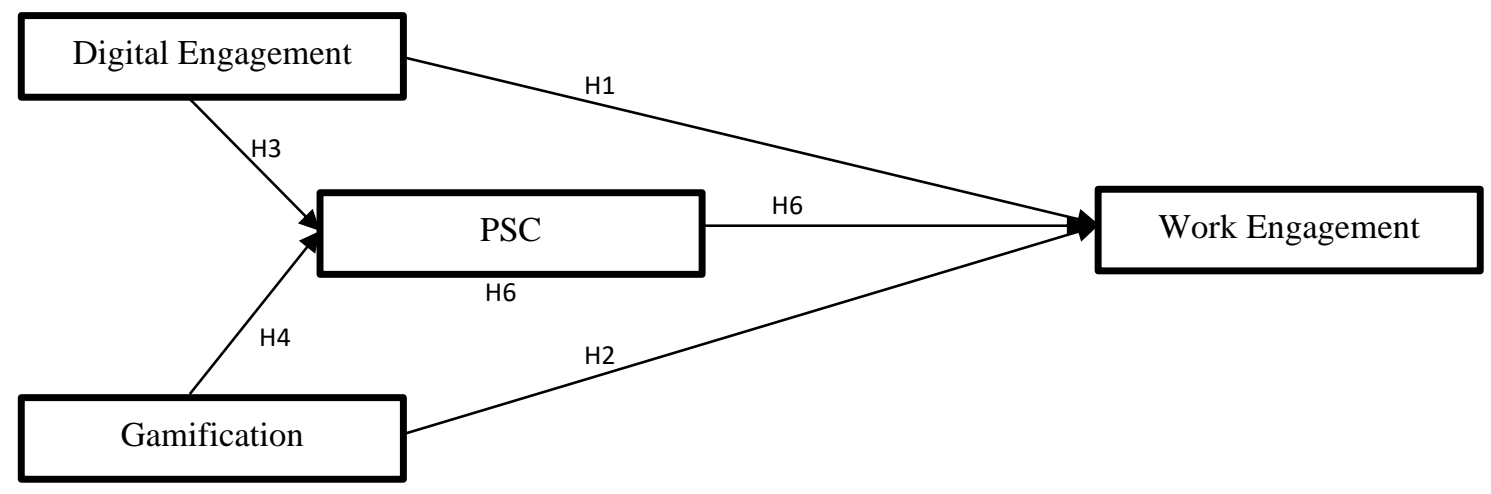

Figure 1. Research Framework

\section{Construction Measurement}

This study uses primary data collected through surveys conducted by researchers. The questionnaire is designed to measure construction using a rating of $1-5$ on respondents' answers. The score can move from 1 as the lowest score to 5 as the highest score to measure four variables, namely digital engagement, gamification, psychosocial safety climate (PSC), and work engagement. A score of 1 represents the most disagreeable answer, and a 5 represents the most agreeable answer. A 16-item rating scale was used to measure this construct (Table 2). Scales are used to measure the construction of research taken from the available literature.

Table 2. Construction Measurement

\begin{tabular}{|c|c|c|}
\hline \\
\hline Construct & Indicator/Item & Authors \\
\hline \multirow[t]{4}{*}{ Digital Engagement (DE) } & Basic digital engagement (DE1) & \multirow{4}{*}{$\begin{array}{l}\text { Goswami \& Upadhyay } \\
\text { (2019); Jesuthasan (2017) }\end{array}$} \\
\hline & Beginner digital engagement (DE2) & \\
\hline & Intermediate digital engagement (DE3) & \\
\hline & Advance digital engagement (DE4) & \\
\hline \multirow[t]{4}{*}{ Gamification $(\mathrm{G})$} & Purpose (G1) & \multirow{4}{*}{$\begin{array}{l}\text { Alsawaier (2018); Prasad } \\
\text { et al. (2019) }\end{array}$} \\
\hline & Personal motivation (G2) & \\
\hline & Pengembangan Keterampilan (G3) & \\
\hline & Efek psikologis (G4) & \\
\hline \multirow{4}{*}{$\begin{array}{l}\text { Psychosocial safety climate } \\
\text { (PSC) }\end{array}$} & Management support and commitment (PSC1) & \multirow{4}{*}{$\begin{array}{l}\text { Dollard \& Bakker (2010); } \\
\text { Bakker \& Schaufeli } \\
\text { (2014) }\end{array}$} \\
\hline & Management priority (PSC2) & \\
\hline & Organizational Communication (PSC3) & \\
\hline & $\begin{array}{l}\begin{array}{l}\text { Organizational participation and Involvement } \\
\text { (PSC4) }\end{array} \\
\end{array}$ & \\
\hline \multirow[t]{4}{*}{ Work Engagement (WE) } & Physical (WE1) & \multirow{4}{*}{$\begin{array}{l}\text { (Samsudin \& Hasan, } \\
\text { 2017); Jesuthasan (2017) }\end{array}$} \\
\hline & Emotional (WE2) & \\
\hline & Intellectual (WE3) & \\
\hline & Spiritual (WE4) & \\
\hline
\end{tabular}


Structural Equation Modeling (SEM) with AMOS Program was used to test the model and hypothesis in this research. The indicators formed the constructs to assess the parameters resulted from the goodness of fit. The subsequent analysis was SEM, which applied a similar step to test the parameters resulting from the goodness of fit and the research hypothesis on the causality relationship developed in the model (Ghozali, 2014). Therefore, we tested the questionnaire items by applying confirmatory factor analysis to test the constructs relationship with the indicators (questionnaire validity). CFA model was first conducted to examine convergent validity. We also used composite reliability (CR) and average variance extracted (AVE) to identify convergent validity.

Table 2 explains the difference between each construct and the question item used; the loading value of each construct should be more than 0.6 cut-off point. The test result of construct validity value, variance extract and discriminant validity (DV) in Table 2 show the construct of digital engagement, gamification, psychosocial safety climate and work engagement. DVs are based on the determined statistics cut-off value. Construct reliability $(\mathrm{CR})$ was more than 0.7 , the AVE was more than 0.5 , and DV was more than 0.7 . This study will look at the influence of digital engagement, gamification, psychosocial safety climate and work engagement.

\section{Analysis and Research Result}

The hypothesis testing in this study was done using SEM and the AMOS program. The SEM analysis results in the full model can be seen in Figure 2. On the other hand, explained the outcome of the hypothesis test in the development of SEM. The complete model confirmatory test resulted in a good result, indicating that the goodness-of-fit criteria were met. The structural model was used to describe the research's causality models with tiered relationships.

The outcome demonstrated that the goodness-of-fit criteria satisfied $\mathrm{x}^{2}$ to 385,876 with a probability of 0.058. Both assumptions have been met. The highest GFI score was 0.981, the highest AGFI score was 0.916 , the highest CFI score was 0.907 , the highest TLI score was 0.872 , the highest NFI score was 0.766 , the highest IFI score was 0.817 , the highest RMSEA score was 0.069 , and the highest RMR score was 0.048 . These results indicated that they had met the required cut-off. This indicated that the research model had been accepted and met the necessary criteria (standard). Test result analysis of goodness of fit among digital engagement, gamification, psychosocial safety climate and work engagement is presented in Table 3.

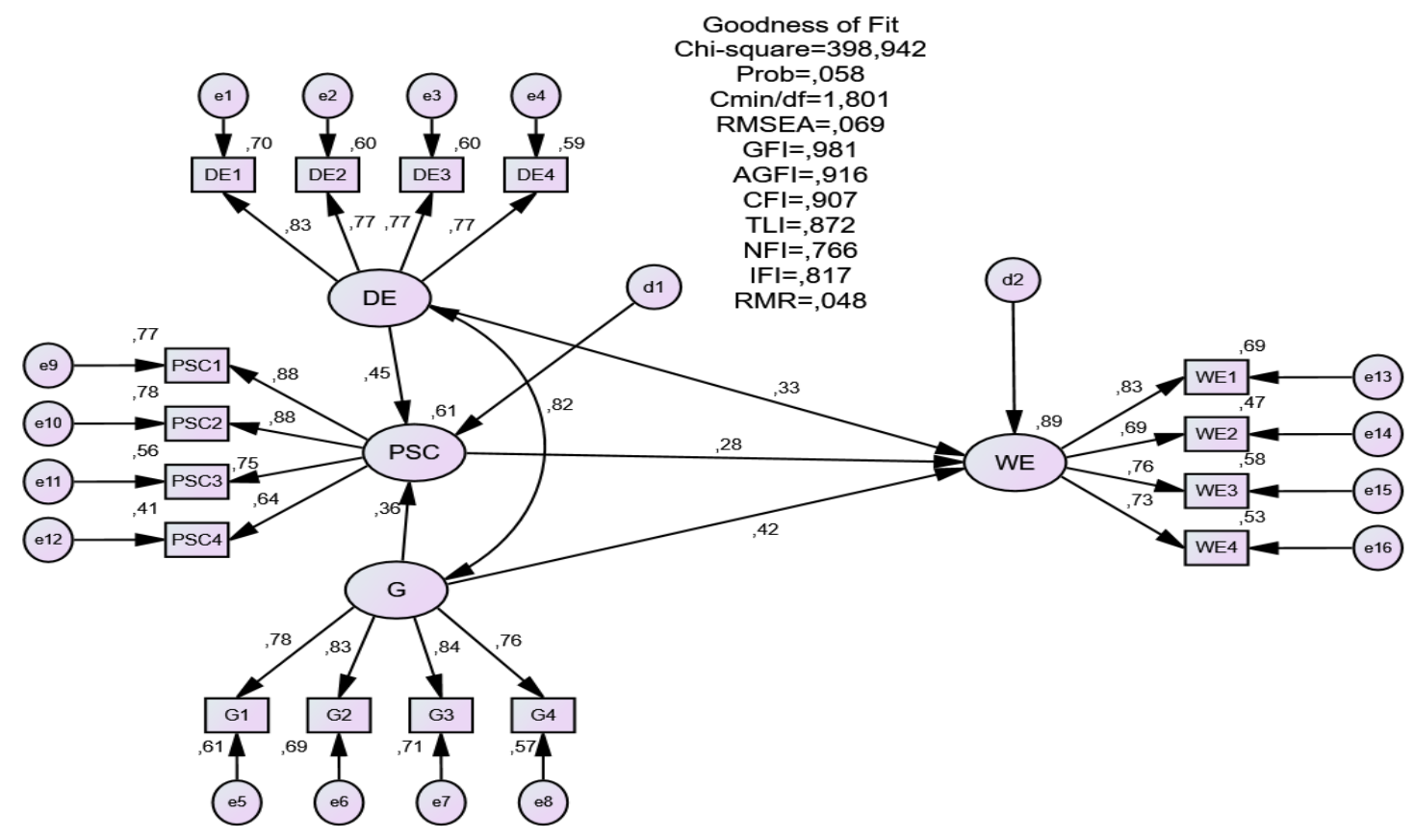

Source: SEM AMOS analysis (2021)

Figures 2. Full Model of the Relationship

The correlations between the indicators of digital engagement, gamification, psychosocial safety climate, and work engagement variables were more than statistically significant. To show this, the value (shown on the diagonal in Table 4) must be greater than the corresponding correlation of latent variables 
on the same row and column. If these conditions are met, then evidence exists that variance is divided between entertainment, trendiness, intimacy, gamification, loyalty, and productivity represented by correlation with items on the scale.

Table 5 shows the standard line coefficients of relationships between entertainment, trendiness, intimacy, gamification, loyalty, and productivity. The results of this study showed that all values of standardized factor loading $>0.5, \mathrm{CR}>0.7, \mathrm{AVE}>0.5$, and $\mathrm{DV}>0.7$ have met the criteria to continue at a later stage. Table 5 also forms six hypotheses. The hypothesis developed in this study is the relationship between aspects of gamification such as entertainment, trendiness, and intimacy in loyalty and productivity programs. Table 5 shows the standard line coefficients of relationships among digital engagement, gamification, psychosocial safety climate and work engagement.

Table 3. Goodness of Fit Index

\begin{tabular}{llll}
\hline \multicolumn{1}{c}{ The goodness of Fit Index } & \multicolumn{1}{c}{ Cut Off Value } & \multicolumn{1}{c}{ Model Penelitian } & \multicolumn{1}{c}{ Model } \\
\hline X2 Chi-Square & expected small & 398,942 & Good Fit \\
\hline Significant Probability & $\geq 0,05$ &, 058 & Good Fit \\
\hline CMIN/DF & $\leq 2,00$ & 1,801 & Good Fit \\
\hline GFI & $\geq 0,90$ & 0,981 & Good Fit \\
\hline AGFI & $\geq 0,90$ & 0,916 & Good Fit \\
\hline CFI & $\geq 0,90$ & 0,907 & Good Fit \\
\hline TLI & $\geq 0,90$ & 0,872 & Marginal Fit \\
\hline NFI & $\geq 0,90$ & 0,766 & Marginal Fit \\
\hline IFI & $\leq 0,90$ & 0,817 & Marginal Fit \\
\hline RMSEA & $\leq 0,08$ & 0,069 & Good Fit \\
\hline RMR & $\leq 0,05$ & 0,048 & Good Fit \\
\hline
\end{tabular}

Source: SEM AMOS analysis (2021)

Table 4. Scale Item for Measures

\begin{tabular}{|c|c|c|c|c|c|}
\hline Construct & Items & $\begin{array}{c}\text { Standardized Factor } \\
\text { Loading }\end{array}$ & $\mathrm{Cr}$ & Ave & DV \\
\hline \multirow[t]{4}{*}{ Digital Engagement (DE) } & DE1 & 0.83 & \multirow{4}{*}{0.957} & \multirow{4}{*}{0.736} & \multirow{4}{*}{0.716} \\
\hline & DE2 & 0.77 & & & \\
\hline & DE3 & 0.77 & & & \\
\hline & DE4 & 0.77 & & & \\
\hline \multirow[t]{4}{*}{ Gamification $(\mathrm{G})$} & G1 & 0.78 & \multirow{4}{*}{0.912} & \multirow{4}{*}{0.684} & \multirow{4}{*}{0.702} \\
\hline & $\mathrm{G} 2$ & 0.83 & & & \\
\hline & G3 & 0.84 & & & \\
\hline & G4 & 0.76 & & & \\
\hline \multirow{4}{*}{$\begin{array}{c}\text { Psychosocial safety climate } \\
\text { (PSC) }\end{array}$} & PSC1 & 0.88 & \multirow{4}{*}{0.938} & \multirow{4}{*}{0.758} & \multirow{4}{*}{0.732} \\
\hline & PSC2 & 0.88 & & & \\
\hline & PSC3 & 0.75 & & & \\
\hline & PSC4 & 0.64 & & & \\
\hline \multirow{4}{*}{ Work Engagement (WE) } & WE1 & 0.83 & \multirow{4}{*}{0.968} & \multirow{4}{*}{0.725} & \multirow{4}{*}{0.728} \\
\hline & WE2 & 0.69 & & & \\
\hline & WE3 & 0.76 & & & \\
\hline & WE4 & 0.73 & & & \\
\hline
\end{tabular}

The findings of this study are also shown in Table 5, which includes six hypotheses. This study's hypothesis is the relationship between digital engagement, gamification, and PSC with work engagement and the impact of gamification on PSC and works engagement. The relationship between digital engagement, gamification, psychosocial safety climate, and work engagement is depicted in Table 5. The $\mathrm{t}$-value and probability indicate the strength and significance of each construct's relationship. Therefore, the discussion of each variable is described as follows: 
H1: Work engagement has a positive effect on digital engagement. The structural path findings indicate a significant and positive relationship between Work engagement and digital engagement $(t=2.287>$ 1.96), of which the significance score is $0.022<0.05$. H1 is accepted.

$\mathrm{H} 2$ : Work engagement has a positive effect on gamification. The structural path findings indicate a significant and positive relationship between Work engagement and gamification $(t=2.922>1.96)$, of which the significance score is $0.003<0.05$. $\mathrm{H} 2$ is accepted.

H3: Digital engagement has a positive effect on PSC. The structural path findings indicate a significant and positive relationship between digital engagement and PSC $(t=2.575>1.96)$, of which the significance score is $0.010<0.05$. H3 is accepted.

H4: Gamification has a positive effect on PSC. The structural path findings indicate a significant and positive relationship between gamification and PSC $(t=2.100>1.96)$, of which the significance score is $0.036<0.05$. $\mathrm{H} 4$ is accepted.

H5: Work engagement has a positive effect on PSC. The structural path findings indicate a significant and positive relationship between Work engagement and PSC $(t=2.504>1.96)$, of which the significance score is $0.012<0.05$. H5 is accepted.

H6: Sobel test is used to test the effect of mediation. This research explains that PSC can mediate the influence of gamification and work engagement. This result can be shown on the test result where the t-statistic is 2.607 , and the p-value is 0.009 . H6 is accepted.

Table 5. Conclusion of Hypothesis

\begin{tabular}{|c|c|c|c|c|c|c|c|}
\hline & & & & $\begin{array}{c}\text { Standardized } \\
\text { path coefficients }\end{array}$ & t-value & $\mathrm{P}$ & Result \\
\hline H1 & WE & $<--$ & $\mathrm{DE}$ & ,338 & 2,287 & ,022 & Significant \\
\hline $\mathrm{H} 2$ & WE & $<---$ & $\mathrm{G}$ & , 420 & 2,922 & ,003 & Significant \\
\hline $\mathrm{H} 3$ & PSC & $<--$ & DE3 & , 445 & 2,575 & ,010 & Significant \\
\hline H4 & PSC & $<---$ & G4 &, 350 & 2,100 & ,036 & Significant \\
\hline H5 & WE & $<---$ & PSC5 & ,289 & 2,504 & ,012 & Significant \\
\hline H6 & WE & $<--$ & PSC <--- G & - & 2.607 & ,009 & Significant \\
\hline
\end{tabular}

Note: *Significant at $p \leq 0.05$; if $t$-value $\geq 1.96$

Source: SEM AMOS analysis (2021)

The results show that aspects of digital transformation through digital engagement and gamification are good predictors for work engagement. The relationship between digital transformation and work engagement measures how far the components influence in strengthening work engagement. The same thing is also found in research by Goswami \& Upadhyay (2019). In the review of digital engagement and gamification variables in the influence of PSC has a positive influence. This is because the technology tools provided by companies with personal internet use, moreover the intensive, widespread, and pivotal use of the internet for work encourages engagement between work and personal life, increases enthusiasm and dedication in the workplace, and boosts productivity (Vayre \& Vonthron, 2019).

The results of exploratory research show that digital engagement has changed the way workers relate to coworkers and digital organizations and technology. This strengthens the research of Jesuthasan (2017). However, other factors such as organizational culture act as a significant determinant of transformational leadership and work attachment. Research that discusses the use of digital game-based learning and gamification in secondary school science affects student engagement and learning (Khan et al., 2017). Leadership has a significant positive effect on performance, while employees involved in their work will have high performance in an organization (Bhuvanaiah \& Raya, 2016). The results of this study strengthen the results of research by Lockton et al. (2012), which shows digital engagement has a significant effect on sustainability engagement in the workplace.

The results of this study reveal the effectiveness of gamification, highlighting how employees perceive corporate gamification. It also shows a positive and significant relationship between employees' perceptions of PSC on gamification and employee engagement. Prasad et al. (2019), in their research, showed the same results. However, there are differences with other variables such as practices and procedures to maintain the health and safety of employees psychologically also influence work engagement. This study argues from the results of Ërgle \& Ludviga (2018) research that gamification has a positive and significant effect on job satisfaction, but there is no effect on work engagement.

This study also explains that the concept of gamification can be applied in business to involve employees and customers, learning and development, performance improvement, recruitment, and others. 
However, gamification still needs to be developed and build a solid theory to reach its maximum potential and needs to be aligned with company goals to be appropriately implemented to prevent failure (Gupta \& Gomathi, 2017). The findings demonstrated that gamification could be used as a powerful tool to improve company performance outcomes. In a business context, HR's role in policy development and implementation of employee engagement is critical. Gamification can increase employee engagement and position oneself in a more strategic role within the organization by Lawande et al. (2016).

This research shows that gamification is a way that companies can improve and develop the way they engage various stakeholders. Gamification will generally be successful if the company can align the gamification design with the player's (target) specifications. Kevin Werbach (2012) revealed that the concept of gamification by playing while doing business could make it easier for users because it is exciting and fun. This research shows that Gamification is not always about making games. Gamification made HR more fun and engaged without destroying their credibility and motivated employees to keep learning. Developing a comprehensive engagement framework of gamification for reflective learning (Silpasuwanchai et al., 2016). Engagement is an important benchmark for gamification success amidst increasing digital technology capabilities (Saha \& Pandita, 2017).

The concept of gamification, this research also provides clarity of opportunities in the user's perception of psychological effects that are easily implemented. This strengthens Bakker \& Schaufeli (2014) research, which refers to employees' perceptions of the extent to which the organization is committed to maintaining employee psychological well-being. They provide feedback or replies shown by their dedication to their work. For example, by providing work engagement as their best effort when working. For this reason, each variable proves that there is a significant positive relationship in increasing work engagement.

\section{Conclusions, suggestions, and limitations}

The problems faced in technological developments and during the pandemic are transforming the habits of employees who are usually offline to online work engagement. This study proves that the variables compiled, namely the influence between digital engagement and gamification variables on PSC and work engagement, has a significant positive effect. Aspects of digital transformation through digital engagement and gamification influence perceptions in PSC, which are suitable predictors to increase work engagement. The relationship between digital engagement and gamification channelled through the PSC can measure and prove how far the variable components influence strengthening work engagement.

Digital engagement for employees can increase engagement with digitization. Gamification design theory will help companies to achieve the work engagement of their employees. The application of digital engagement will create knowledge in digital inclusion to participate in online activities. Meanwhile, the concept of gamification in employees will give a sense of pleasure because they will work like playing. In addition, through gamification, employees will feel more motivated and challenged.

Digital engagement and gamification also provide psychological health in digital transformation. PSC's success in digital engagement and gamification reflects the organization's work engagement in managing employee welfare. Other reviews, such as the concept of gamification, give the impression of playing while doing business by providing pleasant feelings and exciting experiences to mediate the effects of a psychosocial safety climate, which will increase work engagement.

The use of digital transformation through digital engagement and gamification contributes to the company overcoming the shift in habits from offline to online. The concept of digital engagement, which produces digitalization and gamification knowledge that gives a pleasant feeling, will impact the psychological effect to increase employee work engagement. However, the advice that can be given to companies is regarding the implementation of digital engagement and gamification. The application of this concept needs to be studied according to the problems that occur in the company. In addition, the demographic and psychological aspects of employees cannot be equated with one another. The managerial process policy on leadership is needed to target the company's needs precisely.

This study has limited sources of information for employees who do not understand the digital components that exist in the company. Some employees cannot maximize the benefits and potential provided by the company to explore digital transformation, such as digital knowledge and the concept of gamification. As a result, in data collection, some respondents are not appropriate in filling out the questionnaire. Then, with government policies through PPKM and WFH, it is difficult for researchers to dig deeper into employee information, which can only be done through google forms. However, with the acceleration of the digitalization era and facing a pandemic, this research can be developed as future research in the face of digital transformation that can increase work engagement. 


\section{References}

Alsawaier, R. S. (2018). The effect of gamification on motivation and engagement. International Journal of Information and Learning Technology, 35(1), 56-79. https://doi.org/10.1108/IJILT_02-2017-0009

Arief Dwi Saputra, Alfina Rahmatia, M. (2021). How personal factors grow students , interest in entrepreneurship. Jurnal Manajemen Dan Pemasaran Jasa, 14(1), 61-76. https://doi.org/10.25105/jmpj.v14i1.8336

Arief Dwi Saputra. (2020). Pelajar Berwirausaha. Why not? Palangka Raya: CV. Narasi Nara.

Badan Pusat Statistik. (2020). Analisis Big Data Ditengah Masa Adaptasi Kebiasaan Baru.

Bakker \& Schaufeli. (2014). Work Enagagement. Angewandte Chemie International Edition, 6(11), 951957.

Bakker, A. B., Boyd, C. M., Dollard, M., Gillespie, N., Winefield, A. H., \& Stough, C. (2010). The role of personality in the job demands-resources model: A study of Australian academic staff. Career Development International, 15(7), 622-636. https://doi.org/10.1108/13620431011094050

Bhuvanaiah, T., \& Raya, R. P. (2016). Predicting employee work engagement levels, determinants and performance outcome: Empirical validation in an information technology organization. Global Business Review, 17(4), 934-951. https://doi.org/10.1177/0972150916645696

Cardador, M. T., Northcraft, G. B., \& Whicker, J. (2017). A theory of work gamification: Something old, something new, something borrowed, something cool? Human Resource Management Review, 27(2), 353-365. https://doi.org/10.1016/j.hrmr.2016.09.014

Dale Carnegie. (2017). Hanya 25 persen millennials yang setia kepada perusahaan - Dale Carnegie. viewed Juny 13, 2021

Dollard, M. F., \& Bakker, A. B. (2010). Psychosocial safety climate as a precursor to conducive work environments, psychological health problems, and employee engagement. Journal of Occupational and Organizational Psychology, 83(3), 579-599. https://doi.org/10.1348/096317909X470690

Dollard, M. F., Opie, T., Lenthall, S., Wakerman, J., Knight, S., Dunn, S., Rickard, G., \& MacLeod, M. (2012). Psychosocial safety climate as an antecedent of work characteristics and psychological strain: A multilevel model. Work and Stress, 26(4), 385-404. https://doi.org/10.1080/02678373.2012.734154

Ērgle, D., \& Ludviga, I. (2018). Use of Gamification in Human Resource Management: Impact on Engagement and Satisfaction. https://doi.org/10.3846/bm.2018.45

Fujimoto, Y., Ferdous, A. S., Sekiguchi, T., \& Sugianto, L. F. (2016). The effect of mobile technology usage on work engagement and emotional exhaustion in Japan. Journal of Business Research, 69(9), 315-323. https://doi.org/10.1016/j.jbusres.2016.02.013

Gallup. (2017). State of the global workplace. In Employee Engagement Insights for Business Leaders Worldwide. viewed Juny 13, 2021

Garrick, A., Mak, A. S., Cathcart, S., Winwood, P. C., Bakker, A. B., \& Lushington, K. (2014). Psychosocial safety climate moderating the effects of daily job demands and recovery on fatigue and work engagement. Journal of Occupational and Organizational Psychology, 87(4), 694-714. https://doi.org/10.1111/joop.12069

Ghozali. (2014). Structural Equation Modeling, Metode Alternatif dengan Partial Least Square (PLS). Edisi 4. Semarang: Badan Penerbit Universitas Diponegoro.

Goswami, B. K., \& Upadhyay, Y. (2019). An empirical study on digital transformation and its impact on employee engagement. SSRN Electronic Journal. https://doi.org/10.2139/ssrn.3320668

Gupta, A., \& Gomathi, S. (2017). A review on gamification and its potential to motivate and engage employees and customers: Employee engagement through gamification. International Journal of $\begin{array}{llll}\text { Sociotechnology and } \quad \text { Knowledge } & \text { Development, }\end{array}$ https://doi.org/10.4018/IJSKD.2017010103

Hanaysha, J. (2016). Testing the Effects of Employee Engagement, Work Environment, and Organizational Learning on Organizational Commitment. Procedia - Social and Behavioral Sciences, 229, 289-297. https://doi.org/10.1016/j.sbspro.2016.07.139

Helsper, E. J., \& Eynon, R. (2013). Distinct skill pathways to digital engagement. European Journal of Communication, 28(6), 696-713. https://doi.org/10.1177/0267323113499113

Hootsuite, \& W. (2019). Digital 2019: Essential insights into how people around the world use the internet, mobile devices, social media, and E-Commerce. In We Are Social \& Hootsuite. viewed Juny 13, 2021

Jesuthasan (2017). HR's new role: rethinking and enabling digital engagement. Strategic HR Review, 16(2), 60-65. https://doi.org/10.1108/shr-01-2017-0009

Creswell, J.W. (2019). Research Design: Pendekatan Metode Kualitatif, Kuantitatif dan Campuran. Yogyakarta: Pustaka Pelajar. 
Kevin Werbach, D. H. (2012). For the Win: How Game Thinking Can Revolutionize Your Business (Business \&). Wharton School Press.

Khan, A., Ahmad, F. H., \& Malik, M. M. (2017). Use of digital game-based learning and gamification in secondary school science: The effect on student engagement, learning and gender difference. Education and Information Technologies, 22(6), 2767-2804. https://doi.org/10.1007/s10639-0179622-1

Lawande, N., Mohile, R., \& Datta, S. (2016). Gamification and employee engagement: theoretical review on the role of $H R$. 183-198.

Lockton, D., Cain, R., Harrison, D., \& Nicholson, L. (2012). Carbon culture at DECC : Digital Engagement for Sustainability at Work. 1-5.

Michael Beck. (2015). 3 Types Of Engagement: How to improve engagement levels. viewed Juny 11, 2021. https://www.hr.com/en/magazines/recognition_engagement_excellence_essentials/may_2015_re\%0 Acognition_engagement/3-types-of-engagement-how-to-improve-engagement-le_i9b1rrn2.html

Mitchell, R., Schuster, L., \& Jin, H. S. (2020). Gamification and the impact of extrinsic motivation on needs satisfaction: Making work fun? Journal of Business Research, 106(November), 323-330. https://doi.org/10.1016/j.jbusres.2018.11.022

Pesare, E., Roselli, T., Corriero, N., \& Rossano, V. (2016). Game-based learning and Gamification to promote engagement and motivation in medical learning contexts. Smart Learning Environments, 3(1). https://doi.org/10.1186/s40561-016-0028-0

Pham, M. T., \& Avnet, T. (2019). Rethinking regulatory engagement theory. Journal of Consumer Psychology, 19(2). https://doi.org/10.1016/j.jcps.2009.02.003

Prasad, P. J. R. V., Alexander, P. J., \& Misra, S. (2019). Gamification and Employees' Perception: An Empirical Evaluation Using Gamification Effectiveness Scale. IFIP Working Conference, 9(2), 1927.

Robson, K., Plangger, K., Kietzmann, J. H., McCarthy, I., \& Pitt, L. (2015). Is it all a game? Understanding the principles of gamification. Business Horizons, 58(4), 411-420. https://doi.org/10.1016/j.bushor.2015.03.006

Robson, K., Plangger, K., Kietzmann, J. H., McCarthy, I., \& Pitt, L. (2016). Game on: Engaging customers and employees through gamification. Business Horizons, 59(1), 29-36. https://doi.org/10.1016/j.bushor.2015.08.002

Deterding, D Dixon, R Khaled, L. N. (2011). From game design elements to gamefulness: defining" gamification". Proceedings of the 15th International Academic MindTrek Conference: Envisioning Future Media Environments, MindTrek 2011, 9-15.

Saha, D., \& Pandita, D. (2017). Digitalizing human resources through gamification for employee engagement. ELK Asia Pacific Journals, 4. https://doi.org/10.13140/RG.2.2.19809.40807

Samsudin, A. R., \& Hasan, H. (2017). Digital engagement: a preliminary analysis of marginalized youth in the information society. Pertanika Journal of Social Sciences and Humanities, 77-87.

Saputra. (2016). Inquiring the best-fit model of work engagement for digital talent in the palm oil industry. $501-518$.

Saputra, A. D. \& R. A. (2021). Gamification Model as a Business Strategy for MSMEs in Indonesia. Journal of Accounting and Strategic Finance, 4(1), 91-107. http://jasf.upnjatim.ac.id/index.php/jasf/article/view/162

Silic, M., Marzi, G., Caputo, A., \& Bal, P. M. (2020). The effects of a gamified human resource management system on job satisfaction and engagement. Human Resource Management Journal, 30(2), 260-277. https://doi.org/10.1111/1748-8583.12272

Silpasuwanchai, C., Ma, X., Shigemasu, H., \& Ren, X. (2016). Developing a comprehensive Engagement framework of gamification for reflective learning. DIS 2016 - Proceedings of the 2016 ACM Conference on Designing Interactive Systems: Fuse, 459-472. https://doi.org/10.1145/2901790.2901836

Simpson, B. P., \& Jenkins, P. (2015). Gamification and human resources: An overview. Brighton: Brighton Business School., 1-6.

Tuckey, M. R., Bakker, A. B., \& Dollard, M. F. (2013). Empowering leaders optimize working conditions for engagement: A multilevel study. Journal of Occupational Health Psychology, 17(1), 15-27. https://doi.org/10.1037/a0025942

Vayre, E., \& Vonthron, A. M. (2019). Identifying work-related internet's uses at work and outside usual workplaces and hours and their relationships with work-home interface, work engagement, and problematic internet behaviour. Frontiers in Psychology, 1-15. https://doi.org/10.3389/fpsyg.2019.02118 
